聴平衡覚機能の易受傷性について 過性脳虚血発作惹起動物に上る実験的研究

箕面市立病院耳鼻咽喉科

三好 敏 之

\title{
DIFFERENCE IN SUSCEPTIBILITY BETWEEN AUDITORY AND EQUILIBRIAL FUNCTION IN RABBITS WITH EXPERIMENTALLY-INDUCED TRANSIENT ISCHEMIC ATTACK
}

\section{TOSHIYUKI MIYOSHI, M.D.}

Department of Otolaryngology, Minoh City Hospital, Osaka

\begin{abstract}
Patients with transient ischemic attack (TIA) in the vertebrobasilar artery more often complain of disturbance of equilibrium, such as vertigo or dizziness, than of auditory disorders, such as hearing impairment or tinnitus.

The author induced TIA in rabbits by injecting adenosine diphosphate (ADP) into the right vertebral artery.

Observations of rotatory nystagmus have shown that a peak level of directional preponderance appeared 1 minute after injection of $\operatorname{ADP}(0.3 \mathrm{mg} / \mathrm{kg}$ b.w.) and continued for more than 4 minutes.

On the other hand, the amplitude of auditory brainstem responses (ABRs) presented no significant changes following the injection of ADP $(0.5 \mathrm{mg} / \mathrm{kg}$ b.w. $)$. However, greater amounts of ADP ( 1.0 and $2.0 \mathrm{mg} / \mathrm{kg} \mathrm{b} . \mathrm{w}_{\text {.) }}$ were found to reduce the amplitude of ABR-waves, although significant reduction was observed for only less than 1 minute. This change was represented by flattening of the later part of the waves, with the first wave much less affected.

Electrocochleogrm (E. Coch. G.) have also demonstrated a transient reduction in amplitude 10 seconds after injection of ADP (4.0mg/kg b.w.) with correspondingly rapid recovery. In cases of hypertension due to noradrenaline load or trimethaphan-induced hypotention, reduced amplitudes were more profound and continued longer, returning to its normal range within 1 minute.

Differences in susceptibility between the equilibrial system and auditory system in TIA of the vertebrobasilar artery are discussed.
\end{abstract}

Key words : 一過性脳虚血発作モデル，回転時眼振 聴性脳幹反応, 蝸電図

A $92-0207-25521$

\section{I 緒 言}

近年, 原因不明の「めまい」の発生機序として，椎 骨脳底動脈系の血流障害が注目されている ${ }^{122}$. 椎骨脳

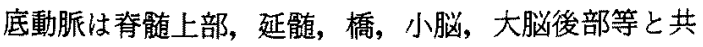
に内耳に対する有力な栄養動脈であり，その血流障害 は聴平衡覚機能に扔いて，内耳末㭇から脳幹を経て大
脳へ至る神経路に対し，広汎に影響する可能性を持つ。 一過性脳虚血発作 (TIA) は，それにより引き起こ された神経症状が24時間以内に消失するものと定義さ れているが゙，根本原因が残っている限り再発する可 能性がある。このような発作を繰り返すうち, 症例の 3 分の 1 は脳梗塞を続発する所から゙，いわゆる切迫 
脳卒中と考光られている5. TIA の発症機序としては， いくつかの説が唱えら机ているが，現今ではアテロー 么硬化した動脈壁より剥離した小血栓が末梢の動脈を 閉塞するとする「微小塞栓説」が有力のようである゙6. 椎骨脳底動脈系の TIA 症状は, 四肢の運動障害及び 知党異常, 構音並びに㱬下障害, 複視, 視力低下等の 他に，身体の平衡障害や回転性めまいと言った平衡賞 についての症状が挙げられているが778)，同じ動脈系に 支配される聴覚系の障害としての難德や耳鳴はTIA の診断基準としては取り上げられては居らず9)，TIA 時の聴覚障害の発現頻度は平衡障害のそれに比べて極 めて低い。

著者は,このように椎骨脳底動脈系の TIAにおいて 平衡覚系と㯖覚系の易受傷性に大きな差のあることに 注目し, 恥賞機能障害の発症状況を知る目的で, TIA 惹起動物を使用して, ENG 及び ABR 記録により平衡 覚並びに聴賞機能を調べた。更にTIAの内耳への関与 をみるため，螖電図の連続記録を行い，これが血圧に より修飾される様態を観察した。

\section{1. 実験動物の準備}

家亮を仰卧位に固定し，1\% Lidocaineによる局所 麻醉下に，右胸部皮南に横切開を加元胸筋を分けて右 鎖骨下動脈を明らかにした後,これを逆行性にたどり， 腕頭動脈上り分岐する右椎骨動脈を確認し，頸椎助横 突孔へ入る所まで追究して周囲組織より分離した ${ }^{10)}$. 既に明らかとなっている右鎖骨下動脈を経由して外径 $0.61 \mathrm{~mm} \sigma$ polyethylene 管 (Clay Adams, Intramedic 7400) を右椎骨動脈内まで挿入し，これを ADP (adenosinediphosphate) の投与経路とした.

更に動物の右大腿動脈を露出させ, ヘパリン加生理 的食塩水を満たした外径 $1.1 \mathrm{~mm} の$ polyethylene 管 (Igarashi，No.9) を挿入固定し, 圧力 transducer (Ailtech, MS-20s)を介して, 圧力計(Telemex, ICP 7703 D) に上り動脈圧の観察を行った。

また，静脈内投与を要する薬物は，動物の左耳静眽 に取った輸液路から注入した。

\section{2. 眼振反応実験}

体重 $2.5 \mathrm{~kg} \sim 3.0 \mathrm{~kg}$ の有色家鬼17羽を用い，右椎骨 動脈へカテーテルを挿入固定後, 腹臥位で円筒型固定 器に入れ，頭部が回転中心に位置するように動物実験 用回転刺激装置（永帛製，MRA）の回転台上に置いた。 負荷した刺激条件は周期 10 秒, 最大回転角 $90^{\circ}$ の振子

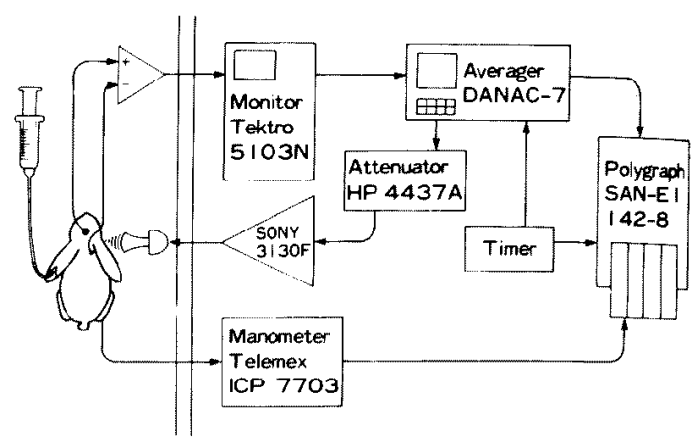

図 1 実験装置け概要

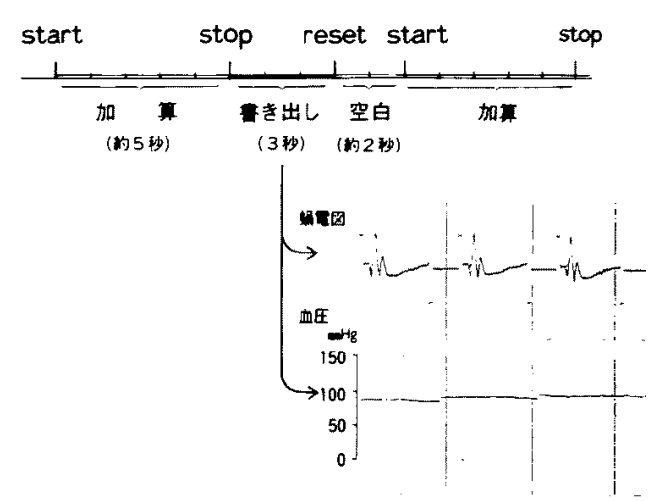

図 2 蝸電図の書き山しのタイミングを示す. 血圧は加算結果ではなく，書き出し時間中の值。

様回転運動である。

眼運動記録は動物の両外眼角後部へ刺入したステン レス針にて眼振図記録を行い，接地電極は耳介に刺入 したステンレス針とした。眼電位の変化は生体電位増 幅器 (三栄側器, 1117-B) を通して，ペンレコーダー (三栄側器，140-A)にて記録した。増幅器の時定数は 原波形については 3.0 秒, 速度波形については 0.03 秒と し，低減通過フィルタの遮断周波数は $25 \mathrm{~Hz}$ とした。

実験に供した家兔 17 羽中，9羽には $0.3 \mathrm{mg} / \mathrm{kg}$ b.w. の ADP を, 8 羽には $2.0 \mathrm{mg} / \mathrm{kg}$ b.w.の ADP を右椎 骨動脈内へ注入した。

\section{3. 聴性誘発電位の記録}

誘発電位は利得 $40 \mathrm{~dB}$ の前置增幅器とレベル調整用 增幅器 (Techtronics, 5A-22) を経て加算解析装置 (Dana Japan, DANAC-7) の外部入力八導いた. 高 域通過フィルタの遮断周波数は $100 \mathrm{~Hz}$ ，低域通過フィ ルタのそれは $3 \mathrm{kHz}$ とし、フィルタのスロープは 6dB/oct.である。 
解析時間を $10 \mathrm{msec}$, 音剌激間隔を $75 \mathrm{msec}$.として 脳幹反心については200回, 蝸電図については50回の力口 算を行った，加算波形は各加算処理の終了と同時にぺ ンレコーダ(三栄側器, 140-A)八転送，描記し，直ち に加算器をりセットして, 次の加算作業に備えるよう タイマーにより制御した。この実駼装置により脳幹反 応汁20秒毎，蝸電図は10秒毎の波形の経時的連続記録 が可能となった。装置の概略を図 1 に, 螖電図の連続 記録例を図 2 に示す。

音刺激は加算解析器に内蔵された波形発生器で得ら れる $4 \mathrm{kHz}$ サイン波の一周期 $(0 \sim 2 \pi \mathrm{rad}$.) を主堌幅器 (SONY, TA $3130 \mathrm{~F}$ ) に導き, 音響変換器 (UNIPEX, P-100 Horn Driver) 在駆動して、クリック音として 動物の右耳人与えた。この際 $\mathrm{CM}$ の影樟や電気的アー チファクトの記録波形八の混入を避ける目的で，刺激 音の一回毎に電気波形を逆位相として睳動した。

香圧の較正は，動物の右外耳道入口部に当たる位㯰 に microphone (Rion, NC-26) を置き，精密騒音計 (Rion, NA-51)により刺激音発生装置に発する $4 \mathrm{kHz}$ 純音の音圧を読み取り(C特性)，その指示值が，刺激 音発生器レベル目盛と同じ数字を示すように主増幅器 の利得を調節した，音刺激の強さは各動物毎に誘発電 位の波形が明瞭に出現する範囲内で可能な限り小さく 設定し，実験中は，その值に固定した。

\section{a) 脳幹反応実験}

体重 $2.2 \mathrm{~kg} \sim 2.5 \mathrm{~kg}$ の日色家鬼6羽に対し, 右椎骨 動脈力テーテルを择入後 pentobarbital $(30 \mathrm{mg} / \mathrm{kg} \mathrm{b}$. w.) の腹腔内投与の軽麻酔下に気管切開を行った。次 いで動物を腹卧位とし動物固定器（ナリシゲ製）に固 定した。䇛験中は左耳静脈に取つた輸液路より臭化パ ンクロニウムを投与し，筋弛緩を計った，更に人工呼
吸器 (Acoma, AR-300) 在用して呼吸管理を行った。 脳幹反応 $(A B R)$ は，動物の頚蓋骨の正中線上で，前 額部と後頭部に立てたステンレスネジを電極しして記 録した。これにより late component 0 振諨をより大 き〈観察できた ${ }^{54}$.アースは左耳介基部八刺入した針 電極とし, 頭蓋骨電極は絶縁と固定を兼水て, 粗科用 レシンにて䫓蓋骨上に被覆した。実䭷に際し，まず対 照として生理的食塩水 $0.5 \mathrm{ml}$ 石椎骨動脈内人注入 L, 次いでADP 0.5mg/kg b.w., $1.0 \mathrm{mg} / \mathrm{kg} \mathrm{b.w.,}$

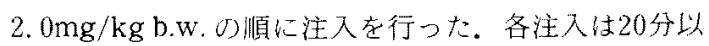
上の時間間隔をあけて行った。

\section{b) 蝸電図害験}

体重 $2.1 \mathrm{~kg} \sim 2.5 \mathrm{~kg}$ の色色家兔 18 羽の右椎骨動脈人 カテーテルを設置後, 腹卧位で頭部を固定し, pentobarbital (30mg/kg b.w.) の腹腔内投与下に在耳 後切開にて中耳骨胞八到達し,歯科用 burrで穿った小 孔さり銀ボール電極を挿入して, ての先端が正円突直 下の粘膜に接するようにリード線を骨胞の呀孔縁入菌 科用レジンで固定した。更に䫒蓋骨正中頙頂部にステ ンレスネジを立て，これと正円空電極とで双極誘導に て蛸電図を記録しな，頭頂電極は㐘科用レジンにて被 覆固定した，実験に際し動物を6 羽ずつ，無呚置群， 高血王群，及び低血圧群の三群に分け，高血圧群に対 してはノルアドレナリン $50 \mu \mathrm{g} / \mathrm{min}$. 口速度で持続静 注を行いつつADP 注入し，低血圧群はカンシル酸 トリメタファン $10 \mathrm{mg} / \mathrm{kg}$ b.w.の静注により血压が低 下した時点でADPを注入したＡDPの注入量は、い ず好の群も $4.0 \mathrm{mg} / \mathrm{kg} \mathrm{b.w.とした。}$

\section{III 結果 \\ 1. ADP 注入と眼振反応}

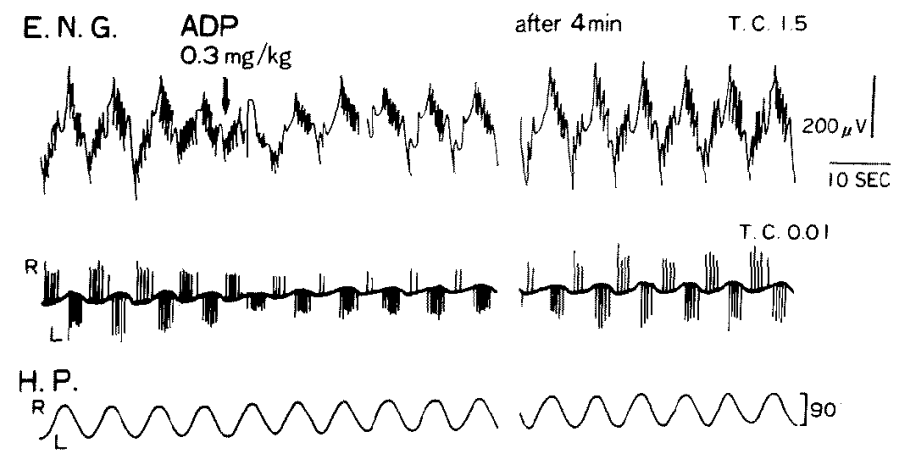

図 3 家鬼の回転中眼振反応の一例 H.P. : head position T.C. : time constant 
BEAT $N$.

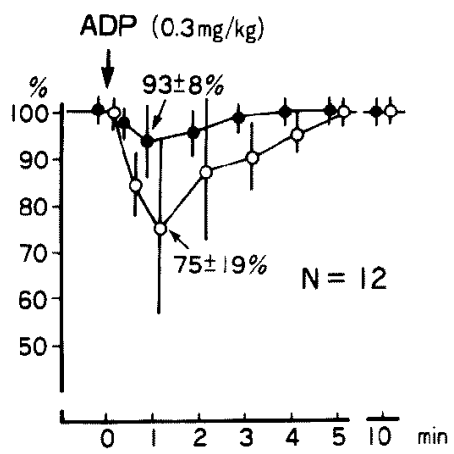

S.P.E. V.

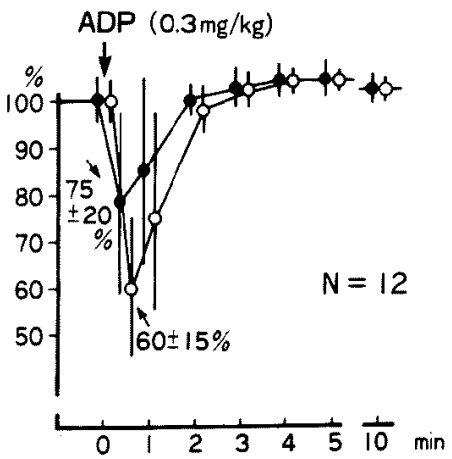

図 $4 \mathrm{ADP}$ 注入時の眼振打数 (BEAT N.) と緩徐相眼球速度 (S.P.E.V.) 推 移、白丸 $(\bigcirc)$ は注入側向きの，黑丸(○) 猅注入側向きの眼振を示す。

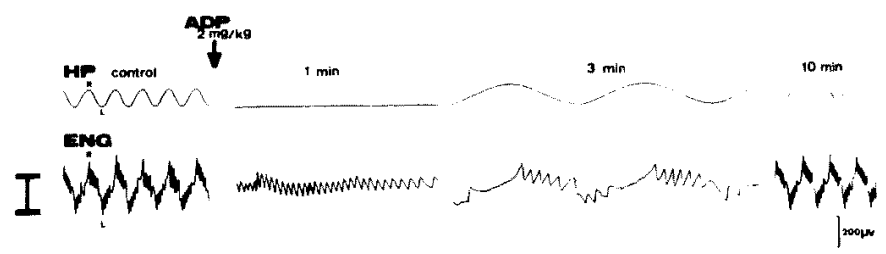

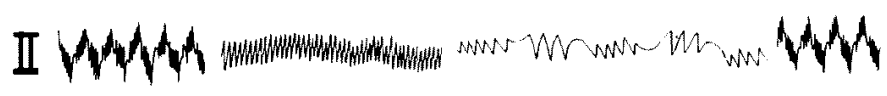

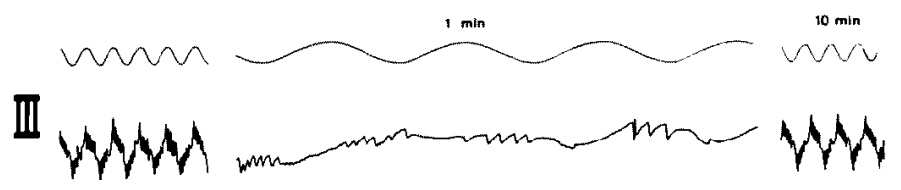

図 5 右惟骨動脈へADP の大量注入を行った場合の眼振反応

家鬼の右椎骨動脈へADP の少量 $(0.3 \mathrm{mg} / \mathrm{kg} \mathrm{b.w.)}$ 注入を行うと回転時限振は直ちに注入側向きの眼振抑 制の状態となり，時間経過に従い次第に回復するのが 観察された (図 3).

これはADPの繰り返し注入に対して再現性があ り，約 4 分以上も持続した。

家鬼 9 羽で延べ 12 回の少量注入を行った結果を記録 紙上で用手計測し，眼振打数と緩徐相眼球速度を，5 周期毎の平均值として算出した。注入前を $100 \%$ とる と, 右方眼振は $75 \pm 19 \%$ (平均土標準偏羔) 八，左方 眼振は $93 \pm 8 \%$, 右方緩徐相速度は60土15\%へ, 左方 緩徐相速度法 $75 \pm 20 \%$ へ低下した後，次第に回復した (図 4).
血圧も一過性の下降を起こすが，眼振反応の回復に 比べると極めて早い時期に注入前の值に戻るのが観察 さ机た。

家鬼 8 羽に対し ADP の大量 $(2.0 \mathrm{mg} / \mathrm{kg}$ b.w.) 注入 を行うと，注入側へ向かう自発眼振を呈した後，回䎐 中眼振が非注入側方向優位を示すものは 4 羽（第 I 群), 非注入側向きの自発眼振を呈し, 回転中眼振は注 入側方向優位であったものは 1 羽(第II群)，更に自発 眼振は解発されず, 非注入側優位の回転中眼振のみを 呈するものは 3 羽（第III群）と，三様の反応が観察さ れた(図5, 図6).

蝸電図実験に際しては更に大量 $(4.0 \mathrm{mg} / \mathrm{kg}$ b.w.) のADP を注入した。この場合,多くの例で注入直後に 
ADP $2 \mathrm{mg} / \mathrm{kg} \quad \longrightarrow$ NYSTAGMUS to LI

I II III

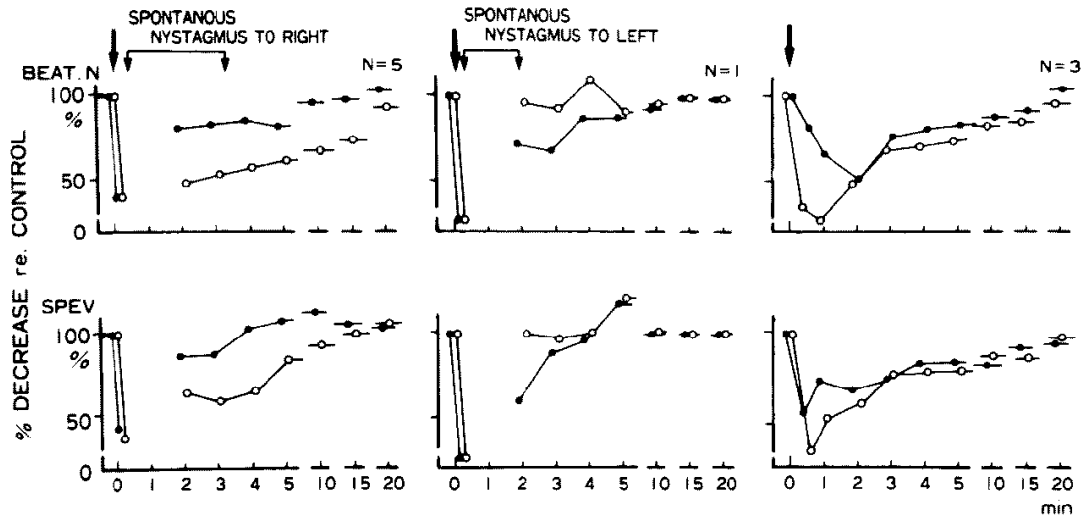

図 6 右椎骨動脈へADP の大量注入を行った場合の眼振打数 (上段)と緩徐相 眼球速度 (下段) の推移

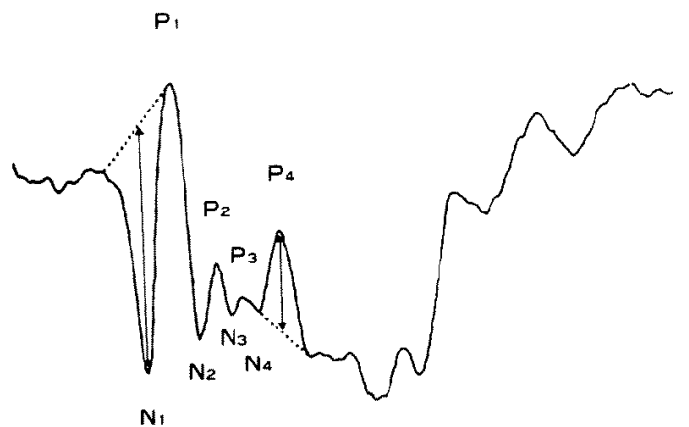

図 7 ABR 波の振幅計測部位



非注入側入の水平の大きな眼球偏位が生じ，次いで注 入側向きの自発眼振が解発された。この自発眼振は約 30 秒以内に消失するが，動物によっては逆方向の眼振 であったり，単に一過性の眼偏位のみであったり，垂 直性眼振を示したりした。はじはは水平性の自発眼振 であっても，注入回数を重ねると垂直性眼振へ変化し て行うものもあり，総して注入回数の堌加に伴い自発 眼振が現れ難くなる傾向が見られた。

2. ADP 注入と脳幹反応

クリック音刺激によるABR は，前額部陽性電位を 上向きの振れとして記録した場合，陽性 peak として

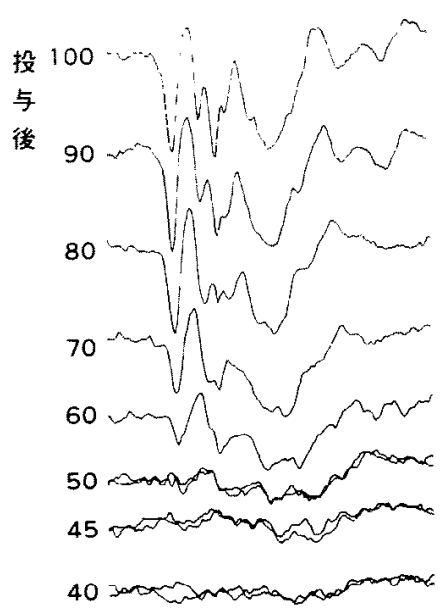

図 8 パンクロニウム投与前（左側）と投与後（右側）のABR 波 
表 1 実娩に供した6例の計測值（生理的食塩水注入前） 刺激レバルは刺激装㯰の目盛を示す。

潜時は刺激音発生用ゲートパルスの立ち上がり よりの時間である。

\begin{tabular}{ccrrrr}
\hline case & 俥 & 激 & \multicolumn{2}{c}{ 振 幅 $(\mu \mathrm{V})$} & \multicolumn{2}{c}{ 潜 時 $(\mathrm{mS})}$. \\
No. & レハル & \multicolumn{1}{c}{$\mathrm{N}_{1}$} & $\mathrm{P}_{4}$ & \multicolumn{1}{c}{$\mathrm{N}_{1}$} & $\mathrm{P}_{4}$ \\
\hline 1 & 95 & 194 & 143 & 1.97 & 3.96 \\
2 & 85 & 240 & 82 & 2.11 & 4.20 \\
3 & 80 & 239 & 55 & 1.96 & 3.93 \\
4 & 75 & 90 & 87 & 2.30 & 4.64 \\
5 & 90 & 138 & 57 & 2.20 & 4.24 \\
6 & 90 & 125 & 67 & 2.01 & 4.05 \\
\hline
\end{tabular}

$P_{1}, P_{2}, P_{3}$ 及び $P_{4}$ ，阷性 peak として $N_{1}, N_{2}, N_{3}$ 及 $ひ ゙ \mathrm{~N}_{4}$ が見られた. early component $の$ 振幅の代表值 として $N_{1}$ の深さを, late component $の$ 振幅の代表值 として $\mathrm{P}_{4}$ の高さを計浿した。 $\mathrm{ABR}$ 波形例と計測点を 図7 に示す。

実験中は非脱分極型筋弛緩剂である臭化パンクロニ ウムを投与して不動化を計ったが，この薬物の ABR 波形への影響は見られなかった（図８）.

表 1 亿，実験见供した 6 例の音刺激強度（刺激レべ 儿目盛の読み）と反応電位を示す。

生理的食塩水 $0.5 \mathrm{ml}$ 及び $0.5 \mathrm{mg} / \mathrm{kg}$ b.w. の注入时 には $\mathrm{ABR}$ 波形には著名な変化は見られなかったが,

表 $2 \mathrm{~N}_{1}$ と $\mathrm{P}_{4}$ の波高と潜時の推移。*印は潜時計測不能例を除外して算出 す。※印は注入前との差が有意であった（paired t-test）

\begin{tabular}{|c|c|c|c|c|c|c|c|c|c|}
\hline 時 間 & 注入前 & 直後 & 20 秒 & 40 秒 & 60 秒 & 80 秒 & 100 秒 & 5 分 & 10 分 \\
\hline & \multicolumn{4}{|c|}{$N_{1}$ 波高の推移 (\%) } & \multicolumn{5}{|c|}{ 平均土標準偏差 $n=6$} \\
\hline 生食》 & 100 & $101.2 \pm 9.9$ & $100.9 \pm 9$ & $1003 \pm 1$ & $4 \pm 1$ & $101.7 \pm 7.8$ & $94.6 \pm 9.4$ & $99.8 \pm 8.5$ & $97.1 \pm 9.4$ \\
\hline ADP $0.5 \mathrm{mg} / \mathrm{kg}$ & 100 & $102.7 \pm 3.6$ & $|104.1 \pm 7.6|$ & $100.2 \pm 5.0$ & $\mid 104.4 \pm 9.7$ & $99.7 \pm 5.4$ & $101.7 \pm 8.5$ & $99.6 \pm 9.3$ & $|10.1 \pm 10.7|$ \\
\hline $1.0 \mathrm{mg} / \mathrm{kg}$ & 100 & $98.1 \pm 9.7$ & $93.1 \pm 11.6$ & $86.6 \pm 25.8$ & $73.6 \pm 38.6$ & $81.4 \pm 40.9$ & $B 2.5 \pm 41.3$ & $88.2 \pm 15.4$ & $\mid 93.6 \pm 12.9$ \\
\hline $2.0 \mathrm{mg} / \mathrm{kg}$ & 100 & $104.9 \pm 10.9$ & $101.2 \pm 11.9$ & $104.1 \pm 14.8$ & $109.4 \pm$ & $108.6 \pm 5.3$ & $\mid 104.4 \pm 8.6$ & $101.0 \pm 5.3$ & $|103.0 \pm 5.7|$ \\
\hline
\end{tabular}

$\mathrm{N}_{1}$ 潜時の推移 $(\%)$

平均土標準偏差 $n=6(* n=5)$

\begin{tabular}{|r|c|r|r|r|r|r|r|r|r|}
\hline 生食水 $0.5 \mathrm{ml}$ & 100 & $100.3 \pm 1.7$ & $100.1 \pm 1.1$ & $100.2 \pm 1.6$ & $100.7 \pm 1.8$ & $100.5 \pm 1.8$ & $100.1 \pm 1.7$ & $100.9 \pm 1.7$ & $100.4 \pm 2.4$ \\
ADP $0.5 \mathrm{mg} / \mathrm{Kg}$ & 100 & $99.3 \pm 1.1$ & $98.8 \pm 1.8$ & $98.9 \pm 1.4$ & $100.2 \pm 0.7$ & $99.5 \pm 1.2$ & $98.9 \pm 1.0$ & $98.7 \pm 1.1$ & $100.2 \pm 1.2$ \\
$1.0 \mathrm{mg} / \mathrm{Kg}$ & 100 & $100.4 \pm 2.5$ & $102.8 \pm 2.7$ & $103.8 \pm 4.8$ & $101.2 \pm 1.5$ & $100.9 \pm 2.8$ & $100.0 \pm 2.0$ & $101.6 \pm 2.1$ & $101.9 \pm 2.5$ \\
$2.0 \mathrm{mg} / \mathrm{Kg}$ & 100 & $101.2 \pm 1.7$ & $101.6 \pm 2.1$ & $102.5 \pm 1.8$ & $99.5 \pm 1.6$ & $100.6 \pm 1.6$ & $100.7 \pm 1.5$ & $100.0 \pm 1.8$ & $100.7 \pm 2.0$ \\
\hline
\end{tabular}

$\mathrm{P}_{4}$ 波高の推移 $(\%)$

平均士標準偏差 $n=6$

\begin{tabular}{|r|c|c|c|c|c|c|c|c|c|c|}
\hline 生食水 $0.5 \mathrm{ml}$ & 100 & $110.4 \pm 16.1$ & $103.4 \pm 19.7$ & $112.0 \pm 22.8$ & $112.0 \pm 25.9$ & $108.2 \pm 22.9$ & $111.6 \pm 21.4$ & $108.1 \pm 12.3$ & $110.8 \pm 15.2$ \\
ADP $0.5 \mathrm{mg} / \mathrm{Kg}$ & 100 & $106.3 \pm 12.8$ & $100.8 \pm 17.8$ & $111.6 \pm 22.0$ & $97.8 \pm 13.1$ & $102.9 \pm 23.3$ & $98.6 \pm 17.7$ & $115.7 \pm 17.8$ & $108.9 \pm 13.3$ \\
$1.0 \mathrm{mg} / \mathrm{Kg}$ & 100 & $92.4 \pm 12.2$ & $84.2 \pm 41.7$ & $61.3 \pm 32.5$ & $77.4 \pm 44.7$ & $79.4 \pm 42.5$ & $88.1 \pm 49.7$ & $99.1 \pm 20.8$ & $98.8 \pm 29.0$ \\
$2.0 \mathrm{mg} / \mathrm{kg}$ & 100 & $96.2 \pm 27.3$ & $75.8 \pm 37.3$ & $68.7 \pm 37.6$ & $93.5 \pm 10.3$ & $101.0 \pm 18.1$ & $107.8 \pm 26.0$ & $100.4 \pm 8.1$ & $100.4 \pm 14.7$ \\
\hline
\end{tabular}

$\mathrm{P}_{4}$ 潜時の推移 $(\%)$

平均土標準偏差 $n=6(* n=5)$

\begin{tabular}{|r|c|c|c|c|c|c|c|c|c|}
\hline 生水 $0.5 \mathrm{ml}$ & 100 & $98.9 \pm 4.0$ & $99.4 \pm 0.6$ & $100.4 \pm 1.0$ & $99.5 \pm 0.6$ & $99.2 \pm 1.6$ & $98.6 \pm 1.4$ & $99.9 \pm 1.0$ & $99.0 \pm 0.5$ \\
ADP $0.5 \mathrm{mg} / \mathrm{Kg}$ & 100 & $1002 \pm 0.8$ & $100.9 \pm 1.1$ & $100.3 \pm 1.2$ & $100.9 \pm 1.2$ & $101.2 \pm 0.7$ & $100.0 \pm 0.8$ & $100.2 \pm 1.5$ & $99.5 \pm 1.1$ \\
$1.0 \mathrm{mg} / \mathrm{kg}$ & 100 & $101.5 \pm 2.2$ & $102.8 \pm 2.8$ & $103.1 \pm 4.7$ & $104.5 \pm 3.2$ & $102.8 \pm 3.1$ & $102.3 \pm 3.0$ & $103.1 \pm 3.6$ & $101.2 \pm 2.2$ \\
$2.0 \mathrm{mg} / \mathrm{Kg}$ & 100 & $100.2 \pm 1.0$ & $102.6 \pm 2.0$ & $101.0 \pm 2.3$ & $101.6 \pm 2.0$ & $101.6 \pm 1.3$ & $101.2 \pm 1.4$ & $99.3 \pm 2.7$ & $101.4 \pm 3.7$ \\
\hline
\end{tabular}

\section{$\mathrm{N}_{1}-\mathrm{P}_{4}$ ピーク潜時差の推移 (mSec.) 平均土標準偏差 $\mathrm{n}=6(* n=5)$}

\begin{tabular}{|r|r|r|r|r|r|r|r|r|r|}
\hline 生甚水 $0.5 \mathrm{ml}$ & $2.09 \pm 0.15$ & $2.03 \pm 0.11$ & $2.05 \pm 0.13$ & $2.09 \pm 0.15$ & $2.05 \pm 0.17$ & $2.03 \pm 0.11$ & $2.03 \pm 0.13$ & $2.07 \pm 0.13$ & $2.03 \pm 0.15$ \\
ADP $0.5 \mathrm{mg} / \mathrm{Kg}$ & $2.01 \pm 0.13$ & $2.03 \pm 0.11$ & $2.07 \pm 0.13$ & $2.05 \pm 0.15$ & $2.05 \pm 0.15$ & $2.07 \pm 0.15$ & $2.03 \pm 0.13$ & $2.05 \pm 0.13$ & $1.98 \pm 0.11$ \\
$1.0 \mathrm{mg} / \mathrm{Kg}$ & $2.03 \pm 0.08$ & $2.07 \pm 0.17$ & $2.05+0.17$ & $2.11 \pm 0.11$ & $2.17 \pm 0.13$ & $2.13 \pm 0.21$ & $2.11 \pm 0.19$ & $2.11 \pm 0.17$ & $2.03 \pm 0.15$ \\
$2.0 \mathrm{mg} / \mathrm{Kg}$ & $2.05 \pm 0.17$ & $2.05 \pm 0.13$ & $2.13 \pm 0.15$ & $2.05 \pm 0.17$ & $2.13 \pm 0.19$ & $2.11 \pm 0.17$ & $2.09 \pm 0.17$ & $2.01 \pm 0.08$ & $2.05 \pm 0.13$ \\
\hline
\end{tabular}




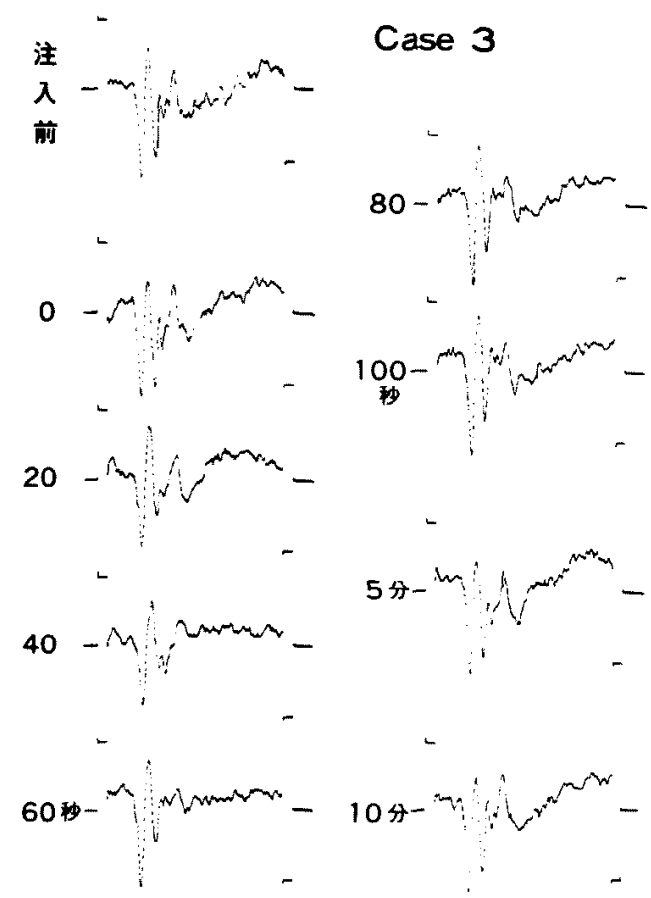

国 $9 \mathrm{ADP}(1.0 \mathrm{mg} / \mathrm{kg} \mathrm{b.w.)}$ 注入時の波型変化例

ADP $1.0 \mathrm{mg} / \mathrm{kg}$ b.w.を注入した時には肉眼的にも明 瞭な波形変化を示すものが 2 例あった（第 3 例と第 6
例)、いずれも振幅の縮小と波形の平坦化であり，特に 後半部に著しかつた（図 9).

$\mathrm{N}_{1}$ と $\mathrm{P}_{4} \sigma$ 振幅及で潜時の時間的推移を，注入前の 值を基準ししてパーセント值で算出し，表 2 ，图 10 , 图11に示与，注入直前の値と注入後の各経過時間每の データの間に差があるかどうかにつき paired $\mathrm{t}$-test により検䇥した。

$\mathrm{N}_{1}$ については ADP $0.5 \mathrm{mg} / \mathrm{kg}$ b.w. 注入時の 100 秒 後 $(\mathrm{p}<0.05) ， 5$ 分後 $(\mathrm{p}<0.05)$ で潜時の短縮（図 10 の左側下段)，2.0mg/ $\mathrm{kg}$ b.w. 注入時 040 秒後 $(\mathrm{p}<$ 0.02) で潜時の延長（図100右側下段），60秒後 $(\mathrm{p}<$ $0.05) ， 80$ 秒後 $(\mathrm{p}<0.05$ ) で振幅の增大（図100右側 上段）が見られた。

$\mathrm{P}_{4}$ についてはADP $0.5 \mathrm{mg} / \mathrm{kg}$ b.w. 注入時の80秒 後 $(\mathrm{p}<0.02)$ で潜時の延長 (図11の左側下段)，1.0mg/

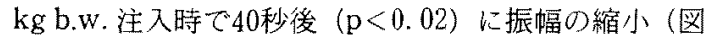
110中央上段)，60秒後（p<0.05）で潜時の延長（図 110 中央下段 $\rangle, 2.0 \mathrm{mg} / \mathrm{kg} \mathrm{b.w}$. 注入時の20秒後 $(\mathrm{p}<$ 0.05）で潜時の延長（図11の右側下段），40秒後（p< 0.05）で振幅の縮小（図11の古側上段），80秒後（p< 0.05）で潜時の延長（図11の右側下段）が見られた。 $\mathrm{ADP}$ 注入後に波形が平坦化して $\mathrm{ABR}$ 潜時の計測 が不可能な埸合は, 残りのデータだけで検定を行った

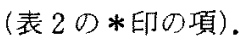

early component $\left(N_{1}\right)$

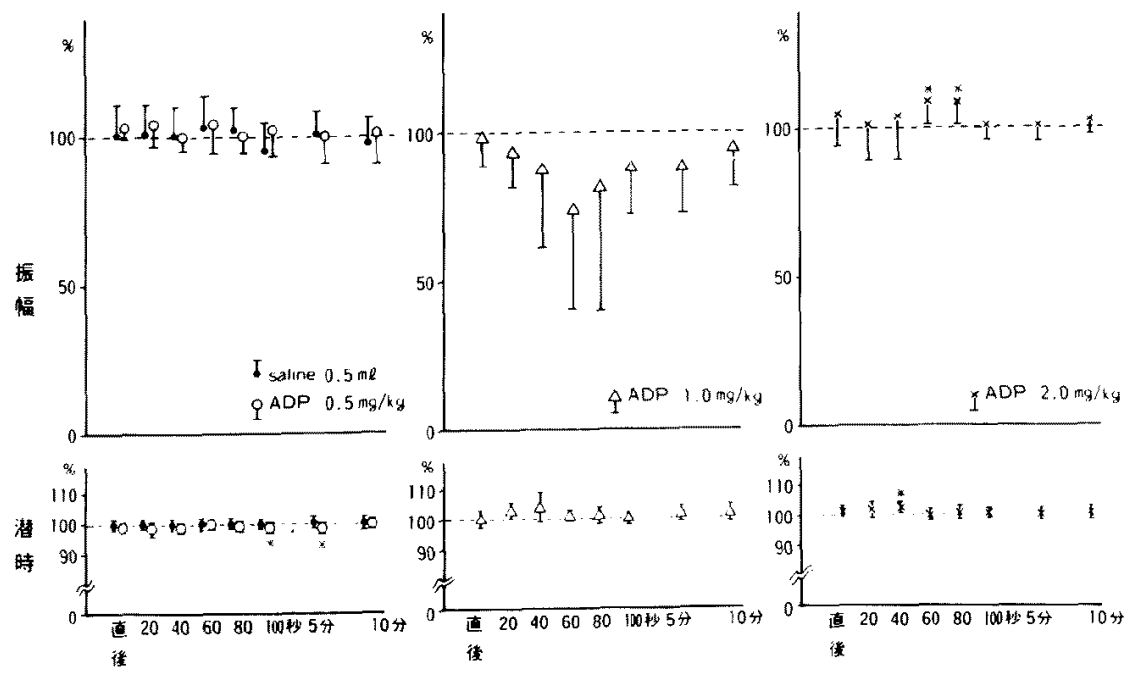

图10 $\mathrm{ABR}$ 波 $\mathrm{N}_{1}$ の推移。左は生理的食塩水 $0.5 \mathrm{ml}$ 注入時及び ADP $0.5 \mathrm{mg}$ / $\mathrm{kg}$ b.w. 注入時, 中心 $\mathrm{ADP} 1.0 \mathrm{mg} / \mathrm{kg}$ b.w. 注入時, 右は ADP 2.0mg/ $\mathrm{kg}$ b.w. 注入時のもの. ※印注注入前との差加有意 (paired t-test) 
late component $\left(P_{4}\right)$
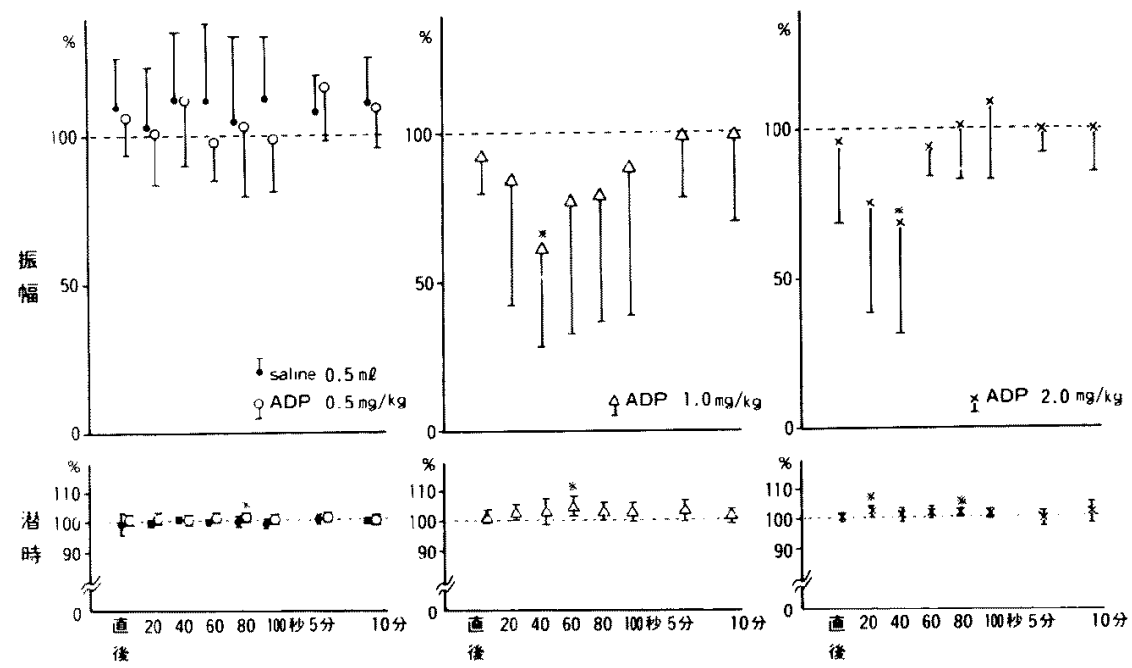

図11 ABR 波 $\mathrm{P}_{4}$ の推移。左活生理的食塩水 $0.5 \mathrm{ml}$ 注入時及び ADP $0.5 \mathrm{mg} /$ $\mathrm{kg} \mathrm{b.w}$. 注入時, 中は ADP 1.0mg/kg b.w. 注入時, 右は ADP 2.0mg/ $\mathrm{kg}$ b.w. 注入時のもの.※印は注入前との差が有意 (paired t-test)

$N_{1}$

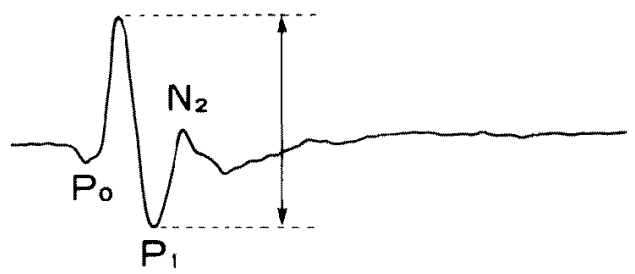

図12 蝸電図上の計測点

\section{ADP 注入と蝸電図}

クリック音刺激による家兔正円空誘導の螎電図は, 頭頂部陽性電位を上向きの振れとした時, 図12のごと くとなった。波形の最大振幅である $\mathrm{N}_{1} \sim \mathrm{P}_{1}$ の頂点間 の高さを蝸電図振幅の代表值として記録紙上で計測し た.ADPを注入する直前の連続10回記録の振幅の平均 值を基準として, 注入後の各時間毎の振幅をパーセン トで算出した（表 3 ）。

無処置群 6 羽では, 各動物へ $1 \sim 2$ 回, 延べ10回の $\operatorname{ADP}(4.0 \mathrm{mg} / \mathrm{kg}$ b.w.) を注入したところ, 振幅の平

表 $3 \mathrm{ADP}$ 注入後の振幅の推移（平均士標準偏差）単位\% 0秒は注入直後の意味である。

\begin{tabular}{|c|c|c|c|c|c|c|c|c|c|}
\hline 秒 & 0 & 10 & 20 & 30 & 40 & 50 & 60 & 70 & 80 \\
\hline $\begin{array}{c}\text { 䠞 } \\
\text { 监 } \\
n=10\end{array}$ & $\begin{array}{l}92.2 \\
\pm 11.8\end{array}$ & $\begin{array}{l}85.8 \\
\pm 13.9\end{array}$ & $\begin{array}{l}93.7 \\
\pm 11.6\end{array}$ & $\begin{array}{l}97.1 \\
\pm 8.9\end{array}$ & $\begin{array}{l}98.2 \\
\pm 8.4\end{array}$ & $\begin{array}{l}98.6 \\
\pm 9.3\end{array}$ & $\begin{array}{l}98.7 \\
\pm 7.2\end{array}$ & $\begin{array}{l}98.4 \\
\pm 10.2\end{array}$ & $\begin{array}{l}95.6 \\
\pm 8.3\end{array}$ \\
\hline 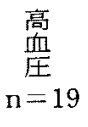 & $\begin{array}{l}83.7 \\
\pm 19.0\end{array}$ & $\begin{array}{l}89.7 \\
\pm 20.8\end{array}$ & $\begin{array}{l}81.2 \\
\pm 22.2\end{array}$ & $\begin{array}{l}81.8 \\
\pm 24.1\end{array}$ & $\begin{array}{l}84.6 \\
\pm 22.5\end{array}$ & $\begin{array}{l}87.7 \\
\pm 21.3\end{array}$ & $\begin{array}{l}90.8 \\
\pm 16.4\end{array}$ & $\begin{array}{l}92.7 \\
\pm 15.1\end{array}$ & $\begin{array}{l}93.3 \\
\pm 15.0\end{array}$ \\
\hline $\begin{array}{c}\text { 低 } \\
\text { 息 } \\
n=27\end{array}$ & $\begin{array}{l}93.9 \\
\pm 17.7\end{array}$ & $\begin{array}{l}81.9 \\
\pm 21.7\end{array}$ & $\begin{array}{l}74.3 \\
\pm 23.1\end{array}$ & $\begin{array}{l}75.8 \\
\pm 22.3\end{array}$ & $\begin{array}{l}85.1 \\
\pm 18.8\end{array}$ & $\begin{array}{l}85.7 \\
\pm 24.7\end{array}$ & $\begin{array}{l}86.3 \\
\pm 26.6\end{array}$ & $\begin{array}{l}91.1 \\
\pm 22.9\end{array}$ & $\begin{array}{l}92.7 \\
\pm 20.9\end{array}$ \\
\hline
\end{tabular}


Amplitude (normal)
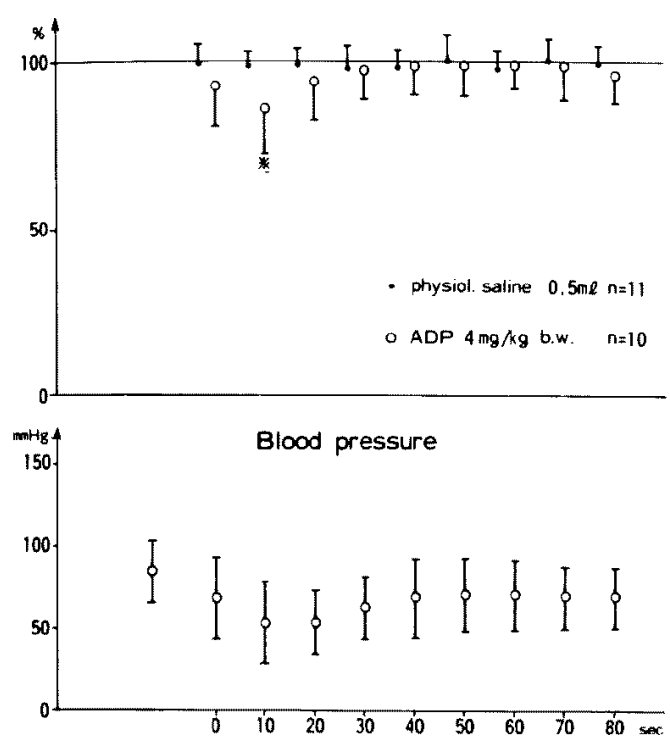

図13 無処置群の蟜電図振幅と血王の推移

Amplitude (hypertension)
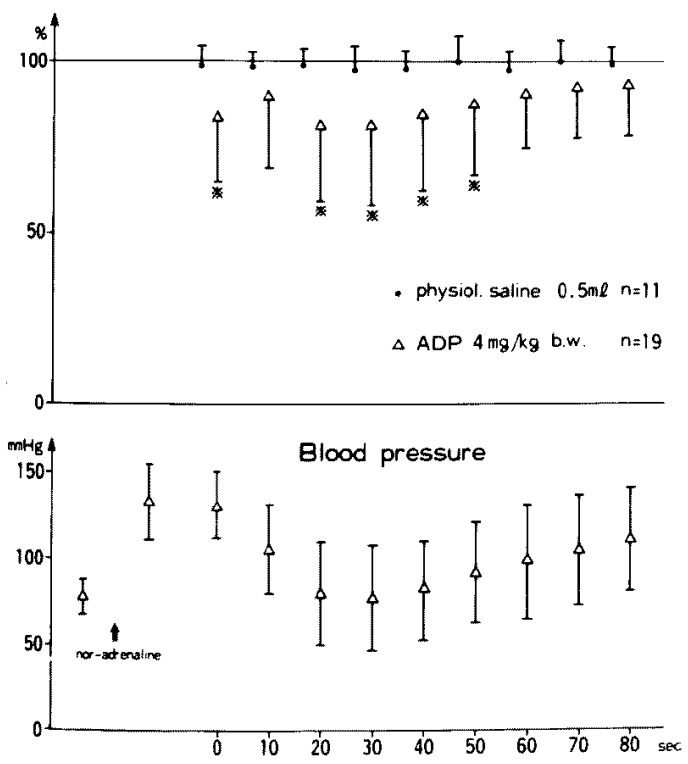

図14高血圧群の䗁電図振幅と血圧の推移

均值は10秒後に $85.8 \%(\mathrm{p}<0.05)$ へと低下した後, 回 復した（図13）。

高血圧群 6 羽では, 各動物へ $2 \sim 4$ 回, 延べ19回の ADP ( $4.0 \mathrm{mg} / \mathrm{kg} \mathrm{b.w}$ ) 注入の結果, 振幅の平均は, 直後に $83.7 \%(\mathrm{p}<0.01), 20$ 秒後に81.2\% $(\mathrm{p}<0.01)$,
Amplitude (hypotension)
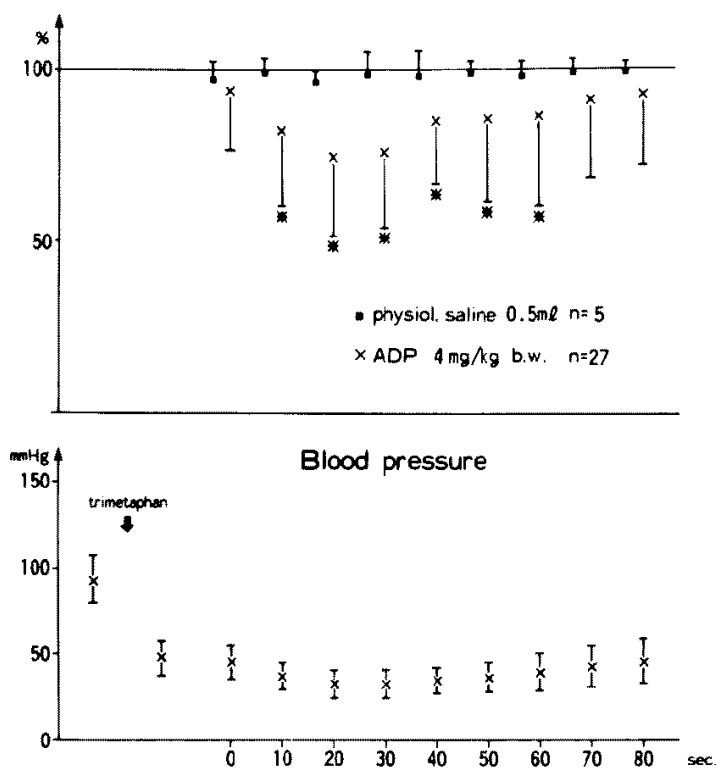

図15低血圧群の蝸電図振幅の血圧の推移

30 秒後に81.8\%（p<0.02），40秒後に84.6\%（p< $0.05) ， 50$ 秒後に87.7\% $(\mathrm{p}<0.05)$ へと低下した（図 14).

低血圧群 6 羽では, 各動物へ 3〜6回, 延べ27回の

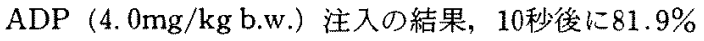
$(\mathrm{p}<0.01), 20$ 秒後に74.3\% $(\mathrm{p}<0.001), 30$ 秒後に 75.8 $\%(\mathrm{p}<0.001) ， 40$ 秒後に85.1\% $(\mathrm{p}<0.02) ， 50$ 秒後に $85.7 \%(\mathrm{p}<0.02), 60$ 秒後に86.3\% $(\mathrm{p}<0.05)$ へと低 下した（図15)。

以上の検定は，生理的食塩水注入時との比較で, Welch 法によって行った.

大腿動脈でモ二タした平均動脈圧は ADP 注入後, 直ちに下降し，經やかに回復したが，この回復は，蝸 電図振幅の回復に比べて，はるかに緩慢であった（図 $13 \sim$ 图15).

\section{IV 考察}

1. モデル動物について

$\mathrm{ADP}$ は強力な血小板凝集作用を持つことが知られ ており ${ }^{11}$ ，これの分解産物であるAMPは血小板凝集 に対し拮抗的に作用する。そのため, 低濃度のADPに より生じた血小板凝集熄は可逆的に解離することが in vitroの実験で観察されている ${ }^{12)}$. Nordöy \& Chandler ${ }^{13)}$ はラットの上大静脈へADP を注入し, 肺 
動脈に生じた血栓を観察し，注入20秒後には著明であ った血栓が60秒〜180秒後には著しく減少乃至消失し ていることを報告した。またJ 家兔での実験で, 動脈カテーテルより持続注入した ADP が腸間膜血管に血栓を生ぜしめるのを短察し，注 入直後の標本では心筋，腎，肺，腸間膜血管に多数の 血小板凝集堖が見られるが，10分後にはこれらの凝集 塊がほとんど消失していたと述べている.Fieschi ら は家鬼の頭蓋骨を開空し，頸動脈より注入したADP がタモ膜動脈に血栓を生ぜしめ，これの生成消失が ADPの注入により反復することを肉眼的に確認した。 臨床的には，新見ら ${ }^{16)}$ はTIA 発作により約10分間の 運動性失語を呈した症例の，発作前後の脳血管写を比 較し，一度は閂塞した動脈が再開通しているのを観察 し，TIA の成因としての microembolus 説を支持する 所見であるとしている。

このように血小板血栓の生成消失及び反復が起こり 得るという事実は，本実験のごとく ADPを椎骨動脈 へ注入して血流障害を惹起する実験モデルが，椎督脳 底動脈系の TIA 病変の格好の simulationであること を支持し，その病態の解析に奇与する所は大きいと考 えられる。

そこでここのうなADPの注入により生じた血小 板血栓が椎骨脳底動脈系のどの部位に閉塞を起こすか については舆味の持たれる所である。この点について 山本ら ${ }^{171}$ は, ADP を注入した後, 直ちに動物の心臟よ り墨计を灌流し，墨汁粒子の到達しない部位を娭索す ることで位流障害部位を推定している。これによると 家鬼では，小脳の片葉，虫部，後葉及び注入側脳幹背 側部，前庭神経核西核の全域に墨汁粒子の非到達域が 多く見られ，蝸牛に拟いは特に頂回転に墨汁の血 管内充盈の欠損を認めるが, ADP を大量に投与しても 約半数は螖牛血流障害の徴候は見られなかったとして いる。

\section{2. 眼振反底について}

1980年に山本と松永 ${ }^{19)}$, 松永ら ${ }^{20)}$ は家息の椎骨動脈 八注入したADP が回転時眼振に，一過性可逆的方方 向僈位を意起することを報告した、今回著者が行った

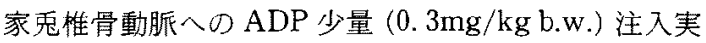
験でも注入側一向かう回転時眼振抑制が 4 分以上も続 くのが観察された，この時，大腿動脈での血圧は極く 一過性の低下を見るが，眼振方向優位性の持続時間よ りは，はるかに短時閒で回復した。松永 ${ }^{18)}$ によれ゙， ADP 注入時には全身血圧の低下と脳幹血流低下が起
こるが，同程度の血圧低下を生じる alpha adrenergic blocking agent 投与時の脳幹部血流には変化が見ら れていない：また山本ら ${ }^{17)} の$ 回転時眼振方向優位性の 観察や, 藤崎ら ${ }^{21)}$ の血管条の直接観察で, ADP を注入 する前に，抗血小板凝集剤を投与しておくと異常所見 からの回復がより速やかであると述べられている、從 って ADPを椎骨動脈八注入することにより生じる眼 振方向優位性の発現は血压低下の直接の結果ではな く，血小板向栓のための椎骨脳底動脈循環蹱害による ものと推定される。

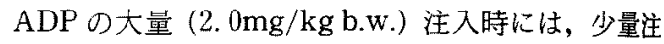
入時には見られなかった自発眼振の解発が見られた。 しかし，この自発眼振の方向等の反応様式は一様ては なかった。これは注入するADP の増量で障害範囲が 拡大し，血管系の解剖学的な variationによる循環系 の固体差が強調され，神経細胞間で興奮と抑制が複雑 に反応し合ったためであるう。また Matsunaga ら は椎骨動脈血流遮断により前庭神経核ニューロンの放 電頻度の一過性增加を示すものが72\%（同側結紮の場 合）もあり，誘発電位では多シナプス反応の方が単シ ナプス反応 $\left(\mathrm{N}_{1}\right)$ よりも早期に隇弱するとしている。

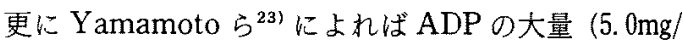
kg b.w.) を注入した場合，内耳電気刺激により訜発さ れる前庭神経核 field potential は，第 1 波よりは第2 波，第 3 波の方が大きな障害を示し，しかも第 1 波は 一過性に振幅增大となる二相性反応を星したとしてい る。これらの事実は椎胃脳底動脈血流障害による脳幹 機能低下が内耳に対して脱抑制現象を引き起こす可能 性を強く示唆し, ADP 大量注入時に解発される自発眼 振の多様性の一因々考之られる。

3. 聴性脳幹反応について

聴覚神経は機能特異性が高く, 内耳に入った音情報 は，大雑把に見て直列的に脳幹を経由し大脳皮質へ伝 えられる。聴性誘発脳幹反応 (ABR) は，これら聴覚 路の中継核の機能状態を推測する手段として広く用い られている。

ADP 注入により引き起こされる椎骨脳底動脈循罢 不全が恥覚路の，どの部位で，どの程度の障害となる かは興味のある所である，以前に著者等がモルモット で行った実験 ${ }^{24)}$ では $7.0 \mathrm{mg} / \mathrm{kg} \quad$ b.w.という大量の ADP を注入しても ABR の遅い成分に, すずかの振愊 縮小が見られたのみであった。しかし本実験のごとく 家鬼では $1.0 \mathrm{mg} / \mathrm{kg}$ b.w.のADPにより ABR 波の振 幅縮小が見られた。この相違は，実験動物の迬いもあ 
るが,家鬼では,より短時間の $\mathrm{ABR}$ 記録を行い得たこ とも重要な点として考えられ, ADP 注入による聴覚障 害が極めて短時間で回復してしまうことを示してい る.

$\mathrm{ABR}$ 各波の起源については臨床例 ${ }^{25) ~ 29)}$ 動物実 験 30 -34) 等の諸家の報告から第一波は聴神経の末梢 端, 後半の波は脳幹に由来するとの示唆が得られてい る。著者は家兔 $\mathrm{ABR}$ の最初の成分である $\mathrm{N}_{1}$ と荤い 成分の $\mathrm{P}_{4}$ に着目して, ADP 注入後の経時的変動を調 ベた.

振幅についてみると, ADP $1.0 \mathrm{mg} / \mathrm{kg}$ b.w. 注入時 は平均で $\mathrm{N}_{4}$ が74\%, $\mathrm{P}_{4}$ は $61 \%$ へと縮小し, $2.0 \mathrm{mg} / \mathrm{kg}$ b.w. 注入時には $\mathrm{P}_{4}$ は $69 \%$ へと縮小しているにもかか わらず， $N_{1}$ はむしろ109\%の一過性増大を示した．更 に障害の著明であった第 3 例と第 6 例の波形を詳細に 検討士ると， $\mathrm{P}_{4}$ 及びそれ以降の波は $\mathrm{N}_{1} よ り も$ 早期に 平坦化し， $N_{1}$ よりも遅れて回復するのが見られた。こ れらの事実は ADP 注入による椎骨脳底動脈循環障害 時の㯖覚機能は聴神経末梢端よりは脳幹部の方が障害 され易いことを意味する。

注入する $\mathrm{ADP} の$ 量を漸增して振幅の変化を見る と, $0.5 \mathrm{mg} / \mathrm{kg}$ b.w. 注入時にはほとんど変動なく, $1.0 \mathrm{mg} / \mathrm{kg}$ b.w. 注入時に振幅の縮小が見られた. しか し注入量を $2.0 \mathrm{mg} / \mathrm{kg}$ b.w.に堌量しても振幅縮小の 程度が，それに応じて大きくなるような単純な関連は なくて、むしろ $\mathrm{N}_{1}$ は増高を示した。この理由は聴覚路 に関係する血流障害が言わば確率的に生起する現象の 故であろうことと，眼振反応の項で述べたごとく，末 梢機能よりは脳幹機能の方が易受傷性が高いことによ る脱抑制 ${ }^{35) ~ 38)}$ のような機序が働いているのではない かと推測される。

潜時について見ると, 本研究での ABR 波の潜時に 関しては見るべき延長所見は得られなかった。(散発的 に有意の延長を呈する部分はある。）ABR 波の潜時, 特にピーク間潜時は, 脳幹での神経興䣫の伝達時間を あらわし，脳幹機能障害時には延長する ${ }^{39) 40)}$. TIA 臨

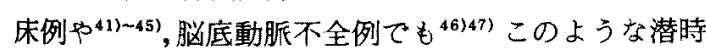
異常が報告されておるり, silent な脳幹障害時の ABR 検查の重要性が強調されている。にもかか加らず本研 究において潜時延長が著明でないのは, 注入回数が, せいぜい数回の急性実験であるため, 神経障害が比較 的軽微で, 加算中に回復してしまう可能性が考えられ る、障害が，より大きくる条件のもとで, 時間軸の 解析精度をもっと細かくすれば，更に詳細な事実が判
明するのではないかと思われる。

4. 蝸電図と血圧について

ADP を注入すると一過性の血圧降下が起こるが,脳 幹反応の第 1 波 $\left(\mathrm{N}_{1}\right)$ の振幅は必ずしも低下ばかりで はなかった、そこで椎骨脳底動脈系 TIA 時の内耳への 関与と血圧変動をより詳しく調べるために蝸電図の経 時的記録を行った，注入するADP 量を脳幹反応実験 よりも更に多く，4.0mg/kg b.w.としたにもかかから ず, 注入10秒後に一過性の振幅縮小を起こすのみで, 直ちに回復した(図13)。すなわち恥神経末梢部の機能 はTIAの影響をより受け難く，秒単位で回復する。一 方血圧は, 振幅の変化よりは, はるかに緩徐な回復を 見せ，低血圧そのものが蝸電図振幅縮小の直接原因で はないことをうかがわせる．この蝸電図変化は迷路動 脈の走行が比較的長くて, 末梢に近い部位での血栓の 生成頻度が低いためと思われる。

Yamamoto et $\mathrm{al}^{48)}$ は一側椎骨動脈を狭窄状態とし た家鬼て，平常血圧では見られない回転時眼振の方向 優位性が,高血圧や低血圧時に出現することを見出し， 脳及び内耳血流の autoregulation の破綻の結果であ ろうとした，そこで高血圧状態(図14), 低血圧状態(図 15)での TIA 時の蝸電図を調べると，いずれも平常血 圧時 (無処置群) と比べ, 障害は強く, 長時間持続し た. Sakagami らはラットの内耳を観察し, 急性高血 圧 $^{49)}$, 急性低血圧 ${ }^{501}$ のいずれの場合も，血管条毛細血 管壁の透過性が充進するのを見出している。これらの 事実は，内耳においても autoregulationを适脱した血 圧のもとでは，TIAによる受傷性が高まることを意味 している。

5. 聴覚系と平衡覚系の受傷性について

内耳には聴賞の受容器としての蝸牛と, 体平衡の受 容器としての半規管及び耳石があり，いずれの系も毛 練胞頂部の瀻毛を物理的に動かして振動や圧について の情報を神経インパルスに変換すると言う共通の生理 学的機構により作動している。内耳に発する神経情報 的第 8 脳神経を上行し, 脳幹を経て大脳へ至るが, こ の間,特に脳幹内では反対側内耳からのインパルスや, 他の感覚情報との間で複雑な好理と統合が行われる。

家兔の一側椎骨動脈へADP 注入して起こさせた 害験的 TIA に拈ける聴覚系と平衡賞系の障害を比較 してみると, 眼振実験では $0.3 \mathrm{mg} / \mathrm{kg}$ b.w.の ADP に より 4 分以上も続く回転時眼振の方向優位性が見られ るのに対し，脳幹反応波の振幅縮小所見は $0.5 \mathrm{mg} / \mathrm{kg}$ b.w.の ADP 注入では見られず， $1.0 \mathrm{mg} / \mathrm{kg}$ b.w. 注入 
時に認められた有意の縮小も60秒以後に消失した。

更に蝸電図記録により，10秒毎の経時的な反応を見 ると ADP $4.0 \mathrm{mg} / \mathrm{kg}$ b.w. に増量しても注入 10 秒後 に一過性の振幅縮小が見られるのみであった。この時， 高血圧状態，低血圧状態として ADP を注入すると障 害持続時間は，延長するものの有意の振幅縮小は，せ いぜい60秒まであった。すなわち德賞系の障害は平衡 党系に比べて，より多量のADP 注入にもかかわらず, むしろ短時間で回復した。

このように聴覚系と平衡賞系の易受傷性に差のある 理由は主として椎骨脳底動脈系血流の特性も聴平衡覚 に関与する中枢神経系の解剖学的, 生理学的特徵によ っていると考元られる。

両側の鎖骨下動脈に発した椎骨動脈は，頸椎の助横 突孔を通り，廷髄側方上り腹側正中へ斜行し，橋後縁 で左右が合流して脳底動脈となる。内耳は，この椎骨 脳底動脈の分枝である迷路動脈により，また脳幹は橋 枝に発する穿通枝により栄責される 動脈の形態を取り，回旋枝とは異なって他動脈との吻 合の可能性を有さないので，管腔の閉塞は，その支配 領域に大きな影響をもたらす。

McDonald \& Potter ${ }^{52)}$ は可視状態とした椎骨脳底 動脈で，一側の椎骨動脈へ注入した色素が脳底動脈内 では注入側半部を流れ，左右より合流する血液が混じ り合わない現象を筧察し，この部位での㬝流現象を記 載している.

先に述ベたごとく，平衡覚系も聴覚系も実験的には， 内耳よりはより中枢位の脳幹での障害が起こり易い。 更に，平衡賞は視覚，深部知覚，迷路知覚等の多くの 感賞要素が中枢神経系内で統合されて成立するので, どの感覚モードに異常があっても平衡異常として認識 せられる ${ }^{53)}$. 他方, 聴覚系はもっぱら音情報のみを取り 扱っている．従って中枢神経系内でも，これらの系に 関与する神経容量の多い分，血流障害の影響索受け易 いことは想像に難くない.

糅てて加えて, 平衡覚系は身体の左右差の神経情報 には極めて敏感であり，むしろ，このことが平衡賞系 の重要な役割の一つであるが，もう一万の聴覚系にお ける左右差の神経情報は主として方向覚に寄与し，純 音域值や周波数選択度に関しては，それ程重要ではな い.

結局，聴平衡覚に対する血流障害の影響は内耳より は脳幹で大きいこと，脳底動脈には層流現象があって 椎骨動脈向流の左右差を反映し易いこと，平衡賞に関
与する神経網の規模が聴覚に関与するものよりも大き いこと，平衡賞は身体左右差の神経情報に，より敏感 であること等の理由により，椎骨動脈に生じた微小血 栓に起因するTIA では,聴賞系よりは平衡覚系の方が 易受傷性が高いと結論される。

\section{$\mathrm{V}$ 結 語}

1. 家兔の椎骨動脈へADP を注入して一過性脳虚 血発作を惹起する実験モデルを用い，回転時眼振，聼 性脳幹反応及び蝸電図記録を行い，神経障害の経時的 推移を調べた。

2. 回転時眼振では $0.3 \mathrm{mg} / \mathrm{kg}$ b.w.の ADP の注入 により非注入側向きの眼振方向優位性が現われ，4分 以上も持続した。この現象は可逆的で, ADPの繰り返 し注入により再現性が見られた。注入するADPを $2.0 \mathrm{mg} / \mathrm{kg}$ b.w. とすると自発眼振の解発が見られた。

3. 聴性脳幹反応は ADP $0.5 \mathrm{mg} / \mathrm{kg}$ b.w. 注入時に

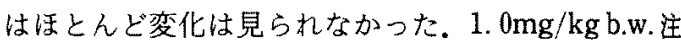
入時には early component $\left(\mathrm{N}_{1}\right)$ の振幅縮小は見られ るものの統計学的に有意ではなく, late component $\left(\mathrm{P}_{4}\right)$ の振幅は注入後 40 秒で有意の縮小が見られた。 $2.0 \mathrm{mg} / \mathrm{kg}$ b.w. 注入時には $\mathrm{N}_{1}$ はむしろ増高し, $\mathrm{P}_{4}$ の 振幅の有意の縮小は40秒間に留まった，波形変化は late component の平坦化に端を発し,これよりも遅れ て $\mathrm{N}_{1}$ の振幅縮小が見亏れた，回復に際しては $\mathrm{N}_{1}$ の 方がより早く振幅を增すのが見られた。

4. 蝸電図 AP の振幅縮小は $4.0 \mathrm{mg} / \mathrm{kg}$ b.w.の $\mathrm{ADP}$ 注入でも20秒後には回復を示した.ノルアドレナ リン投与による高血圧状態では ADP 注入後50秒ま で，トリメタファン投与による低血圧下では60秒まで AP 振幅の縮小がみられた。高血圧下よりも低血圧時 の方が，より頻回の ADP 注入に耐えた。

5. 眼振反応の異常は聴性誘発反応の変化に比べ, より少ない ADP 量でより長時間持続した。これは TIA 臨床例で，蝸牛症状の発現よりもめまいの訴え が，圧倒的に多いことに対応する所見と考えられた。

\section{文献}

1）松永 亨, 松永 喬, 古川 裕, 佐野光仁他: 椎骨動

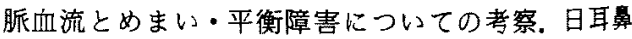
$80: 139-144,1977$.

2）松永 亨：原因不明のめまいの発生機序。耳鼻と臨床 $26 ; 911-926,1980$.

3) Millikan $\mathrm{CH}$, Bauer RB, Goldschmidt J et al: A 
classification and outline of cerebrovascular diseases II. Stroke 6:564-616, 1975.

4) 山口武典, 平田 温: 一過性脳虚血発作 (TIA) と冠動 脈疾患。臨床科学 $17: 17-24 ， 1981$.

5）田崎義昭, 澤田徽：一過性脳虚血発作一成因お上び 治療一。日本臨床 $34: 64-71,1976$.

6）福内靖男, 森田陽子, 一條真琴, 田中耕太郎：TIAの 成因: Thromboembolism 説とHemodynamic 説. 日 本臨床 40:2002-2207，1982.

7) McDowell FH : Transient cerebral ischemia : Diag. nostic considerations. progress in cardiovascular diseases XXII : 309-324, 1980.

8）山口武典, 長木淳一郎：めまいと脳血管障害. 臨床と研 究 $52: 375-380,1975$.

9) Heyman A, Leviton A, Millikan $\mathrm{CH}$ et al: Tran. sient focal cerebral ischemia: Epidemiological and clinical aspects. Stroke 5:277-284, 1974.

10）佐野光仁，松永 亨：椎骨㨫底動脈循䍙障害の実験的 研究. Equilibrium Res·35:68-69, 1976.

11) Gaarder A, Jonsen J, Laland $S$ et al : Adenosine diphosphate in red cells as a factor in the adhesiveness of human blood platelets. Nature 192 : 531$532,1961$.

12) Born GVR: Aggregation of blood platelets by adenosine diphosphate and its reversal. Nature 194 : 927-929, 1962.

13) Nordöy A, Chandler AB: Platelet thrombosis induced by adenosine diphosphate in the rat. Scand J Haemat 1 : 16-25, 1964.

14) J $\phi$ rgensen L, Hovig $T$, Rowsell $C$ et al : Adenosine diphosphate induced platelet aggregation and vascular injury in swine and rabbits. Amer $\mathrm{J}$ Pathol $6: 161-176,1970$

15) Fieschi $C$, Battistini N, Volante $F$ et al: Animal model of TIA: An experimental study with intracarotid ADP infusion in rabbits. Stroke 6: $617-621,1975$.

16）新見次男, 澤田 徹, 栗山良紘, 金子尚二：TIA 発作 時及び発作後の脳血管写所見一embolus の証明とその 消失一, 脳卒中 4:281-282，1982.

17）山本好一，松永 亨，久保 武: 家完のADPによる実 験的循環障害に及ぼす抗めまい剂の影響について。一 とくに振子様回転時眼振の変化を指標として－Equilibrium $\operatorname{Res} 41: 252-257,1982$.

18）松永 亨：め宗いの発生機序一自律神経系の関与につ いて一. 日耳鼻第84回総会宿題報告モノグラフ：5859, 1984.
19）山本好一，松永 亨：ADPに上る一過性椎骨脳底動脈 循環障害と家兔前庭眼反射について。日耳䁷 83 ： 709,1980 .

20）松永 亨, 山本好一, 佐野光仁, 久保 武: ADPによ 万一過性椎骨脑底動脈循環障害と家鬼振子様回転時眼 振について。目鼻 $83: 1311-1312 ， 1980$.

21）藤崎恭大, 山本好一, 吉田渟一, 松永 亭, 石田 稳他: 蝸牛微小循環の直接観察 (第 1 報) -ADP, ノルエピネ フリンの影響一。 日耳疂 $88: 128-137,1985$.

22) Matsunaga $T$, Sano $M$, Yamamoto $K$, Kubo $T$ : Vestibular neuronal function during ischemia. Response of vestibular neurons to vertebral and carotid artery occlusion in rabbits. Adv OtoRhino-Laryngol 25 : 184-191, 1979.

23) Yamamoto $K$, Matsunaga $T$, Kubo $T$ et al : Effects of adenosine diphosphate administration on the vestibulo-oculomotor reflex of rabbits. Otolaryngol Head Neck Surg 89 : 1030-1036, 1981.

24）三好敏之，松永 亨，山本好一：ADPによる一過性椎 管脳底動脈循環障害とモルモットABR替時につい て. 日耳睤 84: 1196-1197，1981。

25) Starr A, Achor LJ : Auditory brain stem responses in neurological disease. Arch Neurol 32:761-768, 1975.

26) Starr A, Hamilton AE: Correlation between confirmed sites of neurological lesions and abnormalities of far-field auditory brainstem responses. Electroencephalogr Clin Neurophysiol 41: 595-608, 1976.

27) Stockard, JJ, Rossiter VS: Clinical and pathologic correlates of brain stem auditory response $a b$ nomalities. Neurology $27: 316-325,1977$.

28）潜本 勲, 石山陽事: 聴性脳幹反応に上る脳幹障害の 局在診断. 臨床胛波 $22: 42-52,1980$.

29) M $\phi$ ller AR, Janetta PJ, M $\phi l$ ler MB : Neural generators of brain stem evoked potentials. Results from human intracranial recordings. Ann Otol 90 $591-596,1981$

30) Lev, A, Sohmer, $\mathbf{H}$ : Sources of averaged neural responses recorded in animal subjects during cochlear audiometry (Electrocochleogram). Arch Klin Exp Ohr-Nas-und Kehlk Heilk 201 : 79-90, 1972.

31) Buchwald, JS, Huang C-M : Far-field acoustic response: Origins in the cat. Science $189: 382-384$, 1975.

32）安藤一郎：BSR の奏験的研究：下丘破壊によるBSR の変化. Audiology Japan $20: 210-220,1977$. 
33) Maurer K, Mika H : Early auditory evoked potentials (EAEPs) in the rabbit. Normative data and effects of lesions in the cerebello-pontine angle. Electroencephalogr Clin Neurophysiol 55 : 586-593, 1983.

34) Wada S-I, Starr A: Generation of auditory brain stem responses (ABRs). I. Effects of injection of a local anesthetic (Procain $\mathbf{H C l}$ ) into the trapezoid body of guinea pigs and cat. Electroencephalogr Clin Neurophysiol $56: 326-339,1983$.

35) Przybylski A : Activity pattern of visceral cortex neurons during asphyxia. Experimental Neurology $32: 12-21,1971$.

36) Heiss W-D, Hayakawa T, Waltz AG: Cortical neuronal function during ischemia. Effects of occlusion of one middle cerebral artery on singleunit activity in cats. Arch Neurol 33: 813-820, 1976.

37) Rubinstein M, Hildesheimer M, Muchnik C et al : A rheological model for research on cochlear hypoxia. in Portmann M and Aran J-M (eds) : INSERM 5-7, Sept, 1977, Vol.68, pp. 289-294.

38) Hall III JW, Mackey-Hargadine JR, Edmund Kim $\mathrm{E}$ : Auditory brainstem response in determination of brain death. Arch Otolaryngol 111 : 613-620, 1985.

39) Gilroy J, Lynn GE, Ristow GE et al: Auditory evoked brain stem potentials in a case of "Locked in" syndrome. Arch Neurol 34: 492-495, 1977.

40)水越鉄理：小脳・脳幹障害に対する神経耳科的アプロ 一千. 新渴医学会雑誌 $93 ： 543-550 ， 1979$.

41) Kjær M: Localizing brain stem lesion with brain stem auditory evoked potentials. Acta Neurol Scand $61: 265-274,1980$.

42) Ragazzoni A, Amantini A, Rossi L et al : Brainstem auditory evoked potentials and vertebral-basilar reversible ischemic attacks. in Courjon $\mathrm{J}$, Maugiere F and Revol M (eds) Clinical Applications of Evoked Potentials in Neurology. Raven press, New York, 1982, pp. 187-194.

43) Rizzo PA, Pozzessers G, Pierelli F et al : Longitudinal study of brainstem auditory-evoked responses in patients with vertebro basilar reversible ischemic attacks. Europ Neurol 22 (suppl. 2) : 54, 1983.

44) Baldy-Moulinier M, Rondouin G, Touchon J et al : potentiels êvoqués auditifs du tronc cérêbral et pathologie ischémique du syntème vertêbrobasilaire. La presse Médicale 29 : 3098-3101, 1983.
45) Baldy-Moulinier M, Rondouin G, Touchon J et al Brain stem auditory-evoked potentials in the asses. ment of the transient ischemic attacks of the arterial vertebrobasilar system. in Fieschi C, Lenzi GL and Loeb CW (eds) : Effects of Aging on Regula. tion of cerebral Blood Flow and Metabolism, Karger, Basel, 1984, pp. 216-221.

46) Maurer K, Marneros A, Schäfer $E$ et al: Early auditory evoked potentials (EAEP) in vertebral basilar insufficiency. Arch Psychiat Nervenkr 227 : 367-376, 1979.

47) Kaji R, McCormick F, Kameyama $M$ et al : Brainstem auditory evoked potentials in early diagnosis of basilar artery occlusion. Neurol 35:240-243, 1985.

48) Yamamoto K, Kubo T, Matsunaga $T$ : Effects of asymmetric vertebral blood flow upon the vestibulo-ocular reflex of the rabbit. Arch Otorhinolaryngol 241: 195-202, 1985.

49) Satagami M, Sano M, Matsunaga $T$ : Ultrastructural study of the effect of acute hypertension on the stria vascularis and spiral ligament. Acta Otolar. yngol (Stockh) $97:$ 53-61, 1984.

50) Sakagami M, Sano M, Tamaki H et al: Increased capillary permeability of the stria vascularis to HRP, induced by experimental acute hypotension in rats. Acta Otolaryngol (Stockh) 98:53-60, 1984.

51) Gillian LA : The correlation of the blood supply to the human brain stem with clinical brain stem lesions. J Neuropathol Exp Neurol 23: 78-108, 1964.

52) McDonald DA, Potter JM: The distribution of blood to the brain. J Physiol 114: 356-371, 1951 .

53）小松崎 篤: 聴覚系と前庭系の機能的差異についての 一考察一主として前庭系の立場より一. Audiology Japan 12:93-102, 1969.

54）高島荘二, 納 一功, 金川清人：遗伝性高指血症ウサギ (WHHL -...Rabbit) の内耳障害の研究, Audiology Japan 25 : 293-294, 1982.

稿を終えるに当たり，ご指導並びに御校閲を睗りました 大阪大学医学部耳鼻咽喉科学教室松永亨教授に克心より深 的申し上げます。また実験に際しての山本好一技官のご語 力に感謝致します。なお, 本研究の一部は第27回及び第28回 日本オージオロジー学会において発表した。

（原稿受付 昭和63.4.11日） 